\title{
Management of Sub-ungual Glomus Tumor of the Finger Tips
}

\author{
Nakul Kumar Datta ${ }^{1,}$, Ashraful Islam ${ }^{1}$, Palash Kumar Aish ${ }^{1}$, Monisha Datta ${ }^{2}$, \\ Suvendu Kumar Banik ${ }^{2}$ \\ ${ }^{1}$ Department of Orthopaedic Surgery, Bangabandhu Sheikh Mujib Medical University, Dhaka, Bangladesh \\ ${ }^{2}$ Anwer Khan Modern Medical College, Dhanmondi, Dhaka, Bangladesh
}

\section{Email address:}

nkdatta123@yahoo.com (N. K. Datta)

${ }^{*}$ Corresponding author

\section{To cite this article:}

Nakul Kumar Datta, Ashraful Islam, Palash Kumar Aish, Monisha Datta, Suvendu Kumar Banik. Management of Sub-ungual Glomus Tumor of the Finger Tips. Advances in Surgical Sciences. Vol. 9, No. 1, 2021, pp. 10-14. doi: 10.11648/j.ass.20210901.13

Received: May 3, 2021; Accepted: May 20, 2021; Published: May 27, 2021

\begin{abstract}
Background: Glomus tumors present as painful lesions especially in colder weather, most commonly at finger tips. Glomus tumors are hamartomas that account for $1 \%$ to $5 \%$ of all soft tissue tumors of the hand. These tumors are usually benign. High-resolution magnetingresonence imaging (HR-MRI) is useful in the diagnosis of patients with subungualglomus tumor, excellent diagnostic informationin detecting the occult lesion. Objective: present study was aimed at delineatingcommon presentation and long term treatment outcome. Materials \& methods: This prospective study was done from January 2004 to july 2019. We found 30patients diagnosed as having sub-ungualglomus tumorsin finger tips and thumbover 15 yearsperiod and which were operated in hand unit in the Department of orthopaedic surgery, Bangabandhu Sheikh Mujib Medical university (BSMMU) Dhaka, Bangladesh. The data were collected included demographics, presenting symptoms, duration, physical examination, treatment and recurrence. Results: The mean duration of symptoms before presentation was 3.2 years (range 6 months to 15 yrs) Mean age at presentation was 33.7 years (range 20 to 65 yrs.) andfemale to male ratio 20:10. Thirteen (13) patientshad left hand involvement among them ring finger were 06, index finger were 04, middle finger were 02 , and thumb 1 and 17 patients had right hand involvement amongthem ring finger were 06 , index finger were 05 , middle finger were 03 and little finger were 03 . Clinical and radiological assessment were made preoperatively. All the lesionsinvolvedthe sub- ungual region. The mean size of the lesion was $3.5 \mathrm{~mm}$ (range 2.5 to $10 \mathrm{~mm}$ ). All the patients confirmed by histopathological examination. No recurrence in this study and nail change were 03 . Transungual approachto be simple procedure which can reduce the chances of recurrence by allowing examination of entiresub ungual region. Nail deformities are minimal if adequate care is taken during surgery. Conclusion: The diagnosis of glomus tumor is largely clinical butHR-MRI is also helpful in diagnosis of patient with sub- ungualglomus tumor. Complete surgical excision offers the only prospect of complete cure. Early diagnosis of glomus tumor is important to avoid lengthy treatment delays.
\end{abstract}

Keywords: Glomus Tumor, Sub-ungual, Finger Tips

\section{Introduction}

Glomus tumors are neoplasm of normal glomus body. These arerare tumors and may affect any area of the body, up to $75 \%$ occur in hand and approximately $65 \%$ of these are in the finger tips particularly in sub-ungual location $[1,2]$, though pulp lesionsare also been reported [3-5]. Normal Glomus bodies are thoughtto aidin the regulation of skin circulationand highly concentratedin the finger tipsparticularly beneath the nail. Solitary glomus tumor usually present as painful locations. Multiple lesions may painless $[1,6]$. They classically present with a triad of symptoms which include pain, pinpointtenderness and hypersensitivity to cold. This presentation is presented to enablea clinical diagnosisin 90\% of cases [6-9], patients usually report a long duration of symptom before correctdiagnosis and treatment. They are difficult to diagnosis particularly as they are often small and situated deep in finger tip. Non specific symptoms andunremarkable 
physical examination mean that incorrectdiagnosisand inappropriatetreatments are common place [2-6, 10]. We diagnosed the patients of glomus tumorat sub-ungual area of finger using high -resolution magnetic resonance imaging (HR-MRI) and treated the patients with surgical excision. We present our experience with the management of 30 cases of glomus tumorsat the finger tips treated over a period of 15 years.

\section{Materials and Methods}

This prospective case study had been carried out in hand unit in the department oforthopedics, Bangabandhu Sheikh Mujib Medical university (BSMMU) Dhaka, Bangladesh from January 2004 t0 july 2019. Total 30 patients diagnosed as havingglomus tumor at finger tips and thumb over 15 years period. The data collected included demographics, presenting symptoms, duration, physical examination, treatment and recurrence. The complaints of all patients were excruciatingpain on touching andwith exposure of coldnessin the finger tip. Theclinicalcriteria used to makethe diagnosiswereclassical triad of findingslocalizedtenderness, pain and coldsensitivity. High resolution magnetic resonance imaging is useful in the diagnosis of patients with subungual glomus tumor and all patients were treated by surgical excision and biopsy.

All cases were performed as day cases. One dose of intravenousantibioticwas administered prophylactically about30 minuteprior to the procedure. After preparing and draping the lesion was localized on table before administration of anesthesia. All operation were performedunder loupe-magnification, under regional blockanesthesiaand under tourniquet control.

Sub ungual lesions ofglomus tumors were excised through a transungual approach (Figure 1a \&1b) over the suspected site. All specimens were sent for his to pathological examination. Suturere moved at $7^{\text {th }}$ post operative day. Subsequent follow upwas at 6 to 8 weeksand at 6 months. patients were advised to returnif they experienced any recurrenceof symptoms and post operative nail platedeformity.

\section{Results}

Of the 30 patients included inthe study among them female were 20 andmale were 10 . The mean duration of symptoms before presentation was 3.2 years (range 6 months to 10 . yrs) Mean age at presentation was 33.7 years (range 20 to 65 yrs.) andfemale to male ratio 19:11. Thirteen (13) patientshad left hand involvement among them ring finger were 06, index finger were 04, middle finger were 02, and thumb 1 and 17 patients had right hand involvement amongthem ring finger were 06 , index finger were 05 , middle finger were 03 and little finger were 03. Clinical and radiological assessment were made preoperatively. All the lesions involved the subungual region. The mean size of the lesion was $3.5 \mathrm{~mm}$ (range 2.5 to $10 \mathrm{~mm}$ ). All the patients confirmed by histopathological examination. No recurrence in this study and nail change were 03 . Transungual approachto be simple procedure which can reduce the chances of recurrence by allowing examination of entiresub ungual region. Nail deformities are minimal if adequate care is taken during surgery. Detailed of the patients are summarized in Table 1. MRI was done in all the cases showed the classifiedfindingsof low signal intensity on $\mathrm{T} 1$ eightedimageand marked hypersensitivityon T2 weighted image. Prolonged post operative follow upwas done for all cases. Post operative follow up which was minimum of 6 months (range 6 months to 10 years)

Table 1. Distribution of 30 glomus tumor according to age, sex, side, digit, location, duration before presentation.

\begin{tabular}{|c|c|c|c|c|c|c|c|c|c|}
\hline Case no & Age (year) & $\operatorname{sex}$ & side & Digit & location & Duration before presentation & Size & Treatment & Result \\
\hline 1 & 65 & $\mathrm{M}$ & Left & Ring & subungual & $8 \mathrm{yrs}$ & $10 \mathrm{~mm}$ & Excision & Pain relieved \\
\hline 2 & 42 & $\mathrm{~F}$ & Left & Ring & subungual & $2 y r s$ & $3 \mathrm{~mm}$ & Excision & Pain relieved \\
\hline 3 & 45 & $\mathrm{~F}$ & left & Ring & subungual & $3 y r s$ & $3 \mathrm{~mm}$ & Excision & Pain relieved \\
\hline 4 & 30 & $\mathrm{~F}$ & Right & Little & subungual & $5 y r s$ & $4 \mathrm{~mm}$ & Excision & Pain relieved \\
\hline 5 & 25 & $\mathrm{~F}$ & Right & Ring & subungual & $3 y r s$ & $4 \mathrm{~mm}$ & Excision & Pain relieved \\
\hline 6 & 50 & M & Right & index & subungual & $5 y r s$ & $5 \mathrm{~mm}$ & Excision & Pain relieved \\
\hline 7 & 20 & $\mathrm{~F}$ & Right & index & subungual & 6 month & $6 \mathrm{~mm}$ & Excision & Pain relieved \\
\hline 9 & 36 & $\mathrm{~F}$ & Left & Middle & subungual & $3 \mathrm{yrs}$ & $5 \mathrm{~mm}$ & Excision & Pain relieved \\
\hline 10 & 22 & $\mathrm{~F}$ & Right & Index & subungual & $2 \mathrm{yrs}$ & $4 \mathrm{~mm}$ & Excision & Pain relieved \\
\hline 11 & 24 & $\mathrm{~F}$ & Right & Thumb & subungual & $3 y r s$ & $4 \mathrm{~mm}$ & Excision & Pain relieved \\
\hline 12 & 36 & $\mathrm{~F}$ & left & Middle & subungual & $4 y r s$ & $4 \mathrm{~mm}$ & Excision & Pain relieved \\
\hline 13 & 40 & $\mathrm{~F}$ & Right & Ring & subungual & $4 y r s$ & $3 \mathrm{~mm}$ & Excision & Pain relieved \\
\hline 14 & 40 & M & Right & Ring & subungual & $3 \mathrm{yrs}$ & $3 \mathrm{~mm}$ & Excision & Pain relieved \\
\hline 15 & 36 & M & left & Index & subungual & $3 \mathrm{yrs}$ & $4 \mathrm{~mm}$ & Excision & Pain relieved \\
\hline 16 & 25 & $\mathrm{~F}$ & Right & Ring & subungual & $4 y r s$ & $4 \mathrm{~mm}$ & Excision & Pain relieved \\
\hline 18 & 30 & M & Right & little & subungual & $2 \mathrm{yrs}$ & $4 \mathrm{~mm}$ & Excision & Pain relieved \\
\hline 19 & 42 & $\mathrm{~F}$ & Left & Ring & subungual & $3 y r s$ & $3 \mathrm{~mm}$ & Excision & Pain relieved \\
\hline 20 & 40 & M & Left & Index & subungual & $2 \mathrm{yrs}$ & $3 \mathrm{~mm}$ & Excision & Pain relieved \\
\hline 21 & 25 & M & Right & Middle & subungual & $3 y r s$ & $4 \mathrm{~mm}$ & Excision & Pain relieved \\
\hline 22 & 41 & $\mathrm{~F}$ & Left & Ring & subungual & $5 \mathrm{yrs}$ & $3 \mathrm{~mm}$ & Excision & Pain relieved \\
\hline 23 & 27 & M & Right & index & subungual & $2 \mathrm{yrs}$ & $5 \mathrm{~mm}$ & Excision & Pain relieved \\
\hline
\end{tabular}




\begin{tabular}{|c|c|c|c|c|c|c|c|c|c|}
\hline Case no & Age (year) & sex & side & Digit & location & Duration before presentation & Size & Treatment & Result \\
\hline 24 & 48 & $\mathrm{~F}$ & Left & Index & subungual & $4 \mathrm{yrs}$ & $5 \mathrm{~mm}$ & Excision & Pain relieved \\
\hline 25 & 46 & $\mathrm{~F}$ & Right & Ring & subungual & $4 \mathrm{yrs}$ & $3 \mathrm{~mm}$ & Excision & Pain relieved \\
\hline 26 & 24 & $\mathrm{~F}$ & Right & Little & subungual & 3 yrs & $5 \mathrm{~mm}$ & Excision & Pain relieved \\
\hline 27 & 38 & $\mathrm{~F}$ & Left & Ring & subungual & $3 y r s$ & $4 \mathrm{~mm}$ & Excision & Pain relieved \\
\hline 28 & 44 & M & Right & Middle & subungual & $3 \mathrm{yrs}$ & $3 \mathrm{~mm}$ & Excision & Pain relieved \\
\hline 29 & 32 & $\mathrm{~F}$ & Right & Ring & subungual & $3 \mathrm{yrs}$ & $4 \mathrm{~mm}$ & Excision & Pain relieved \\
\hline 30 & 34 & $\mathrm{~F}$ & Right & Ring & subungual & $3 \mathrm{yrs}$ & $4 \mathrm{~mm}$ & Excision & Pain relieved \\
\hline
\end{tabular}
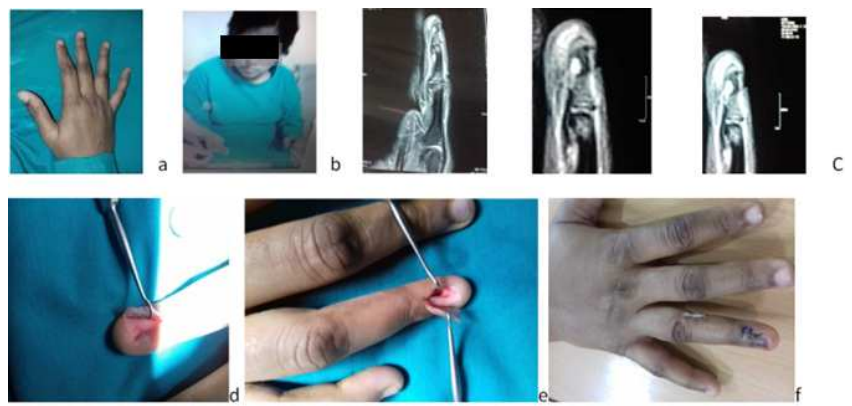

Figure 1. a. Pre operative image 22yrsfemale at right ring finger at sub ungualregion at radial border. $b$. pin point tenderness at lesional area $c$. MRI atring fingershowingwell defined mass beneath the nail plate. $d$. Per operative appearance. e. after removal of glomus tumor. $f$. post operative appearance at 10 days.
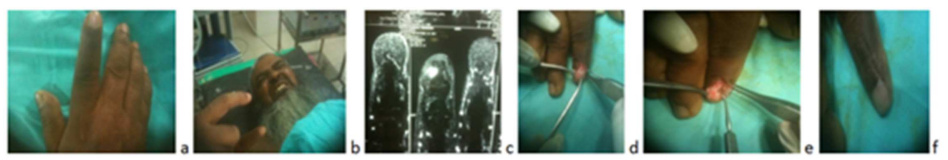

Figure 2. a. pre operative image of 50 yrsmale, glomustumor radial border at subungualregion of right index finger. $b$. Pin point tenderness atlesional area. $C$. MRI of right index finger. $d$. per operative appearance. e. after removal tumor. $f$. post operative appearance at one month

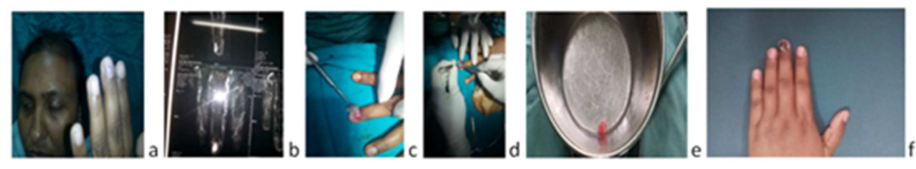

Figure 3. a Pre operative image of 36yrs female, glomus tumor at left middle finger at sub ungual region. $b$. MRI left middle finger c. per operative appearanced. After removal of tumore. excised glomus tumor. $f$. Post operativeat 1 month with changes at pail plate.
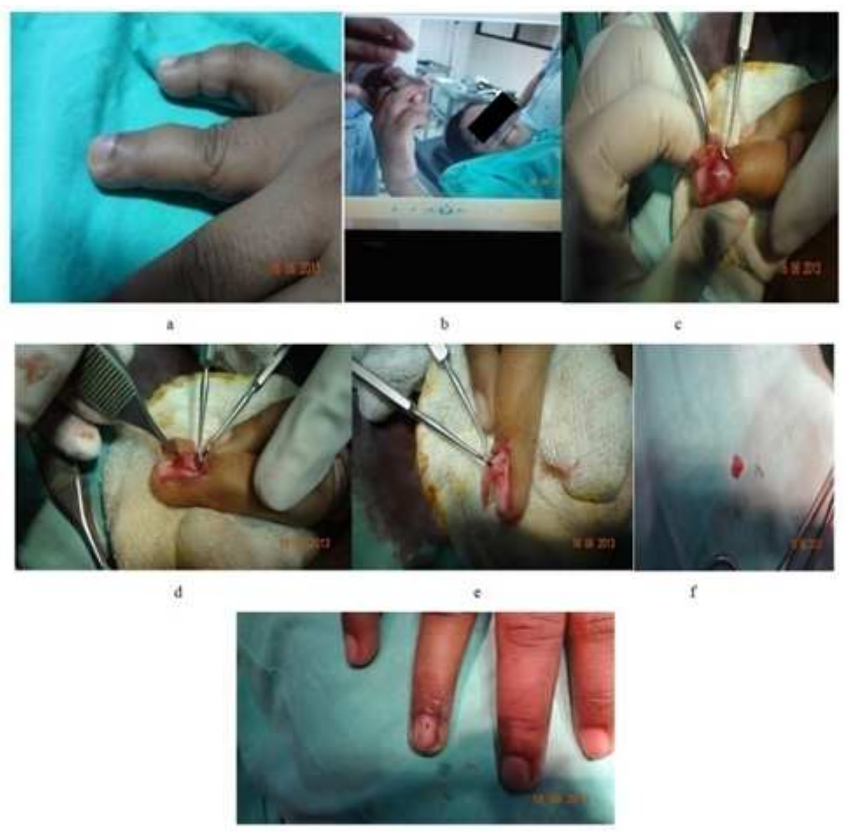

Figure 4. a. Pre operative image of 25 yrs female, glomus tumor at subungual region Right ring finger. b. pin point tenderness at lesionalarea. cd. per operative appearance e. appearance after excision. f. excised tumor $g$. appearance after excision. 


\section{Discussion}

It is difficult to diagnose the patient with glomus tumor from characteristic clinical findings and radiograph. Recently, HR-MRI. has been developed to diagnose small lesion and its usefulness has been reported in diagnosis of glomus tumor in the finger tips which can be detected the mass as is ointence of the dermis of the nail bed on T1 weighted image and hyperintenseon T2weightedimage [1115]. They had a long history of suffering from onset to clinical diagnosis using HR- MRI which dected the mass at distal phalanx. Therefore HR- MRI is considered to be a usefulness method to diagnose glomus tumor in fingers. In all patients symptoms such as pain on touching and exposure to coldness disappeared after surgery and no recurrence was observed. Surgical excision and biopsy for glomus tumor is effective and necessary to confirm the diagnosis and relieve pain [15-18]. However it is important that surgeons understand the accurate localization of the tumor and meticulous surgical plan pre operatively in order to avoid recurrence and nail deformity [18]

Glomus tumor was first described by Wood 1812 and was named by Massonin 1924. [6]. The glomus cells are specialized smooth muscle cells derived, particularly concentrated around dilated vascular spaces. In addition, nervefibers and mast cells may be present in increased numbers. The tumor is exquisitely sensitive to changes in temperature which leads to contraction ofmyofilaments. This results in anincreasein intrcapsular pressure transmitted byunmyelinatednerve fibers leading to perception of pain [19].

Glomus tumors most commonly affect patients in $3^{\text {rd }}$ to $5^{\text {th }}$ decades of lifeas also seen in our study. Although cases have been described in all age group. [20]. A female predominance has been reported previously [20], as was seenin our series as well.

The treatment of Glomus tumor is surgical. [1, 4, 21]

The average delay in diagnosis was 4 years in our series. The transungual approach for excision of glomus tumor is usually recommended $[20,9,22,21,18]$ as it gives the best exposureif the lesion iscompletelysubungual. Replacing the nail plate in its orginal position has been suggested to prevent nail deformities [1]. The main disadvantagereportedwith lateral approachesis thelesser degreeof exposure of the nail bedinsubungual lesions, particularlyin cases of very small tumor [6].

The dence fibrous tissue surround the mass forming pseudo capsule [23]. Based on its histological character the tumorcan be completely removedas a whole if carefuldissectionis madethroughfibrouspsuedocapsule. As such encapsulated tumor could 'pop up' from the cavity.

Early recurrence may occurwithin weeks to months of surgery and presumably reflex in adequate excision and Later recurrence (years) is probably the result development of new tumor [24].

\section{Conclusion}

Glomus tumors presents as painful lesions especially in colder weather in the finger tips. The diagnosis of sub ungual glomus tumor is largely clinical. Radiological examination include HR-MRI is useful in the diagnosis of patients with subungual glomus tumor and gives an excellent information in detecting the occult lesion. Transungual approach is a simple, safe and effective procedure which can reduce the chances of recurrence by allowing examination of entire sub ungual region. The alleviation of pain following surgery is quite gratifying both for patients and surgeon. There is no case of recurrence in this study and nail changes are minimal. Complete surgical excision offers the only prospect of complete cure.

\section{Ehical Issue}

This topic was presentedseveral timesin Bangladesh society for surgery of the hand Conference (BDSSH CON) and in Bangladesh Orthopaedic Society annual Conference (BOS CON) 2016 and also in Management of Hand tumor, in Indian society for surgery of the Hand conference (ISSH CON 2019).

\section{Conflict of Interest}

All the authordo not have any possible conflicts ofinterest.

\section{References}

[1] Carroll RE, Berman AT. Glomus tumors of the hand. J Bone Joint Surg Am 1972; 54: 691-703.

[2] Tang CYK, Tipoe T, Fung B. Where is the lesion? Glomustumours of the hand. Arch PlastSurg 2013; 40: 492-5.

[3] Mathew A. Glomangiomas: Are they rare tumours or rarely diagnosed? Internet J Hand Surg 2012; 3. [cited 2018 Oct 22]; 3 (2). Available from: http://ispub.com/ IJHS/3/2/13861.

[4] Rosner IA, Argenta AE, Washington KM. Unusual volar pulp location of glomus tumor. PlastReconstrSurg Glob Open 2017; 5: e1215.

[5] Kim DH. Glomus tumor of the finger tip and MRI appearance. Iowa Orthop J 1999; 19: 136-8.

[6] Samaniego E, Crespo A, Sanz A. Key diagnostic features and treatment of subungualglomus tumor. ActasDermosifiliogr2009; 100: 875-82.

[7] Baek HJ, Lee SJ, Cho KH, Choo HJ, Lee SM, Lee YH, et al. Subungual tumors: Clinicopathologic correlation with US and MR imaging findings. Radiographics 2010; 30: 1621-36.

[8] Schiefer TK, Parker WL, Anakwenze OA, Amadio PC, Inwards CY, Spinner RJ. Extradigitalglomus tumors: A 20year experience. Mayo ClinProc 2006; 81: 1337-44. 
[9] Tomak Y, Akcay I, Dabak N, Eroglu L. Subungualglomustumours of the hand: Diagnosis and treatment of 14 cases. Scand J PlastReconstrSurg Hand Surg 2003; 37: 121-4.

[10] Montandon C, Costa JC, Dias LA, Costa FHAA, Costa ACM, Daher RT, et al. Subungualglomus tumors: Imaging findings. Radiol Bras 2009; 42: 371-41.

[11] Drapé JL, Idy-Peretti I, Goettmann S, Guérin-Surville H, Bittoun J. 1996. Standard and high resolution magnetic resonance imaging of glomus tumors of toes and fingertips. J Am AcadDermatol 35: 550-555.

[12] Hou SM, Shih TTF, Lin MC. 1993. Magnetic resonance imaging of an obscure glomus tumor in the finger tip. J Hand Surg 18B: 482-483.

[13] Koç O, Kivrak AS, Paksoy Y. 2007. Subungualglomus tumor: magnetic resonance imaging findings. AustralasRadiol 51: B107-109.

[14] Opdenakker G, Gelin G, Palmers Y. 1999. MR imaging of a subungualglomus tumor. Am J Roentgenol 172: 250-251.

[15] Takemura N, Fujii N, Tanaka T. 2006. Subungualglomus tumor diagnosis based on imaging, J Dermatol 33: 389-393.

[16] Carroll RE, Berman AT. 1972. Glomus tumors of the hand. Review of the literature and report on twenty-eight cases, J Bone Joint Surg 54A: 691-703.
[17] Enzinger FM, Weiss SW. 1995. Perivascular tumors. In: Soft tissue tumors. 3rd ed. St. Louis: Mosby; p. 701-733.

[18] Takata H, Ikuta Y, Ishida O, Kimori K. 2001. Treatment of subungualglomustumour. Hand Surg 6: 25-27.

[19] Rohrich RJ, Hochstein LM, Millwee RH. Subungualglomus tumors: An algorithmic approach. Ann PlastSurg 1994; 33: $300-4$.

[20] Song M, Ko HC, Kwon KS, Kim MB. Surgical treatment of subungualglomus tumor: A unique and simple method. DermatolSurg 2009; 35: 786-91.

[21] Acar E. Surgical treatment outcomes of glomus tumor of the finger. Hand Microsurg 2017; 6: 125-9.

[22] Shin DK, Kim MS, Kim SW, Kim SH. A Painful glomus tumor on the pulp of the distal phalanx. J Korean NeurosurgSoc 2010; 48: 185-7.

[23] Kim SH, Suh HS, Choi JH, et al. Glomus tumor: a clinical and histopathologic analysis of 17 cases. Ann Dermatol 2000; 12: 95-101.

[24] Vasisht B, Watson HK, Joseph E, Lionelli GT. Digital glomus tumors: a 29-year experience with a lateral sub periosteal approach. PlastReconstrSurg 2004; 114: 1486e9. 